\title{
Miranda
}

Revue pluridisciplinaire du monde anglophone /

Multidisciplinary peer-reviewed journal on the English-

speaking world

$14 \mid 2017$

Early American Surrealisms, 1920-1940 / Parable Art

\section{C.S. Lewis's parables as revisited and reactivated biblical stories}

Daniel Warzecha

\section{OpenEdition}

\section{Journals}

\section{Electronic version}

URL: http://journals.openedition.org/miranda/9890

DOI: $10.4000 /$ miranda. 9890

ISSN: 2108-6559

Publisher

Université Toulouse - Jean Jaurès

\section{Electronic reference}

Daniel Warzecha, "C.S. Lewis's parables as revisited and reactivated biblical stories", Miranda [Online],

14 | 2017, Online since 04 April 2017, connection on 16 February 2021. URL: http://

journals.openedition.org/miranda/9890 ; DOI: https://doi.org/10.4000/miranda.9890

This text was automatically generated on 16 February 2021.

\section{cc) (i) () $\Theta$}

Miranda is licensed under a Creative Commons Attribution-NonCommercial-NoDerivatives 4.0 International License. 


\title{
C.S. Lewis's parables as revisited and reactivated biblical stories
}

\author{
Daniel Warzecha
}

C.S. Lewis (1898-1963), a scholar, writer and Anglican apologist in the first half of the twentieth century went through an experience of (re)conversion to Christianity in the early nineteen thirties. That experience deeply impacted his thought and sensitivity as a writer with the result that he was soon driven by an evangelizing spirit as shown by his first book. ${ }^{1}$ Throughout his life, as a prolific writer authoring varied work (conferences, radio programmes, children's stories, novels, scholarly studies), he tried to bear witness directly or indirectly to his faith. One of his favorite means was to tell stories copied from the Aristotelian muthoi-pattern with its mythopoetic content, its allegorical and parabolic dimension he kept on revisiting and reactivating. According to Jean Ladrière,

every speech-act is "self-implying" [...] in so far as in every speech-act the speaking subject brings into play his own being according to various procedures that specify his/her as a being subject (knowledge, will, imagination, affectivity, sensitivity etc.) [...] This means, on the one hand, that the speaker necessarily conveys the very frame of his/her existence through his/her words, and in that way, his or her words really express who he or she is. But it also means, on the other hand, that language, as far as he or she takes responsibility for it, resonates on the very movement of existence and gives a shape to it. If the word expresses somebody's existence, on the contrary there is an inductive effect of speech upon existence. This is why one cannot use language in a neutral way. There is an irreducible gravity in somebody's speech and an indeclinable responsibility towards what it accomplishes (Ladrière 32). ${ }^{2}$

2 Lewis was very much a self-implied writer. He used to get involved personally in his scholarly thoughts; he staged his life directly through two autobiographies and even indirectly in his fiction. One could apply to Lewis what Paul Ricoeur wrote about imagination as "something that shapes human experience [...] It is through fiction that one provides individual or common experience with narrative form" (Ricœur 340-1). ${ }^{3}$ So Lewis's speech "really expresses who he is" (Ladrière 32). On the contrary, his friends' words, the words read from Latin, Greek, Biblical or Medieval authors 
impregnated Lewis's thought, determined his writing and impacted his life. That is why there is an irreducible gravity in Lewis's word, because it is part of a cultural, literary and spiritual tradition which is a several thousand years old.

Thus Lewis wrote parable-like stories influenced by other stories he had "decontextualized and recontextualized in his Sitz im Leben" (Ricœur 340). He also retold his life story in a sublimated or fictionalized way. But let's study the Lewisian story in the light of the parable, its traits and its performativity.

What is a parable? My study will be inspired of the parable in the Gospels. It is a kind of snapshot story built on a comparison "The kingdom of heaven is like a mustard seed, which a man took and sowed in his field [...] The kingdom of heaven is like a treasure hidden in a field [...] Again, the kingdom of heaven is like a merchant looking for fine pearls"( Mt. $13: 31,44-5)$. The parable conveys an allegorical dimension and induces a moral or spiritual teaching. It is "enshrined" in a bigger story, the one that depicts Jesus' peculiar itinerary. According to Ladrière,

the evangelical story is altogether organized around a unique event which is the accomplishment of the promises, the new covenant replacing the former law, the proclamation and the accomplishment of the Word of God, of "the mystery which has been kept from all times and generations, but [which] has now been made clear to his saints" (Colossians 1:26), that "mystery of Christ". Yet that event is not immediately obvious (Ladrière 34$).^{4}$

5 As that unique event is not "obvious" it needs to be mediated and metaphorized through parables and stories. And it is worth noticing that Jesus not only tells the parables but he is also often the main protagonist in them. He tells about himself in a story. Moreover part of the parable is enigmatic and that hidden content requires to be interpreted even though the parable cannot be reduced to a definitive interpretation. For Ricœur, "the parable-story offers an itinerary of meanings, which is an open invitation to a work of interpretation" (Ricœur 340). ${ }^{5}$ Furthermore, the parable possesses a timeless and universal quality and it can be transposed in any human situation. Finally the parable produces and reveals something in the listener's mind.

What are the characteristics and the theoretical premises of the Lewisian story? The first one is its intense intertextuality, claimed by Lewis. As a neo-Platonist, he was convinced that the writer neither invents nor creates anything. Like Augustine, he thought that only God creates. Man only copies or imitates what he sees or perceives, and that is his mission and his glory. As a result, any individual or collective story derives from an original story which serves as a pattern or a matrix. So all human stories repeat, reveal and re-effectuate a primordial story in which "the same human experience is at stake" (Ricœur 340).

7 How does Lewis proceeds when he revisits a founding text? I will take the temptation episode in Genesis 3 that Lewis revisited in three fictional works, The Pilgrim's Regress (1933), Perelandra (1943), the second book of the Cosmic Trilogy and The Magician's Nephew (1955), the first tale of the seven Chronicles of Narnia.

8 Even if the biblical story of the temptation is not strictly speaking a parable, it contains nonetheless all the ingredients of the parable. This timeless story stages a primordial and a tragic event: how evil was introduced into mankind through allegorical characters (Adam \& Eve). It contains allegorical elements: two trees, one standing for life and the other one for the knowledge of good and evil, and a snake personifying the tempter. The story carries a spiritual dimension, i.e. man being separated from his 
divine source, plus a metaphysical and moral dimension, i.e. the finiteness and mortality of the human condition. Last but not least, the biblical story offers an itinerary of meanings that requires theological interpretation.

Lewis rewrote the same biblical story pattern which he decontextualized and recontextualized in his fiction. In The Pilgrim's Regress, his first allegorical autobiography, the pilgrim John makes a full-circle journey in time and space and arrives in front of an unbridgeable canyon. Mother Kirk, an allegorical figure standing for the Church in its generic sense, provides him with an explanation by using a parabolic story. In Perelandra, the Green Lady, a kind of Venusian Eve, is tempted by Weston, a venal, unscrupulous scientist who landed on the planet Venus to colonize and exploit it. He is countered and stopped in his seducing attempt by Ransom, a Christ-like figure, and the hero of the three cosmic stories. In The Magician's Nephew, the child Digory must atone for the fault he committed by letting the Witch Jadis into Narnia, which she will invade later in the second book. Digory is then appointed by the lion Aslan to go and fetch a magic apple in a garden on a hilltop where he will be tempted. In the three stories, the temptation scene occurs at a critical moment and a turning point in the plot. Without the explanation about the Great Canyon (an allegory of Adam's sin or Peccatum Adae) John cannot continue his journey. If the Green Lady yields to the temptation, she will not marry the King (who is the eponym of Adam) and the planet will become corrupt and be destroyed. If Digory disobeys and yields to the temptation by eating the magic apple, he will become as dissatisfied and desperate as the Witch who has eaten some fraudulently.

10 Lewis did not reproduce the basic story slavishly. In Perelandra and The Magician, both temptations fail and both tempters (Weston and the Witch) are vanquished. In The Pilgrim's Regress, the temptation episode is illustrated by another parable which sheds light on the story plot: a landowner living in the mountains also owned a valley which he and his children managed. In his goodness and generosity, he wanted to share his valley with tenants, with whom he contracted a perpetual lease, allowing them to leave whenever they wanted. On his land, fruit trees grew and bore fruits that only mountaineers could stand. The landowner warned his tenants about the danger of the fruit. Everything went well until one day one the landowner's rebellious son, called the "land grabber", went down into the valley and convinced the tenant's wife to taste the fruit. She ate it, and gave some to her husband. It brought about an earthquake that provoked a huge abyss, which was then called the Great Canyon.

11 In Lewis's stories metaphors and characters undergo a shift. The forbidden fruit is turned into a magic apple in The Magician and a refreshing fruit in The Pilgrim's Regress. In the allegory, the tempter is the landowner's rebellious son (a reminder of Lucifer, the fallen angel). In Perelandra the tempter is personified as a disincarnated man whereas in The Magician, the temptress is embodied in a witch, as a hypostasis of evil. Lewis conforms to Christian theology that considers evil to be originally external to man who then becomes the receptacle of evil after disobeying God. As Ricœur put it, "man is not the absolute villain but wicked secondly" (Ricoeur 1960, 398-9). ${ }^{6}$ In the Lewisian parables, underlying theological concepts such as the reasons for divine prohibition, the origin of evil or the consequences of disobedience call for clarification and interpretation. In The Magician, the witch repeats the snake's fallacious allusions to Genesis: Aslan, like God in the Bible, does not want the forbidden fruit to be eaten because he wants to keep them all for himself and leave man frustrated forever. Jadis's 
promise of eternity ("Eat it boy, eat it; and you and I will both live forever and be king and queen of this entire world", 150) echoes back the snake's deceptive promise ("God knows that your eyes will be opened as soon as you eat it, and you will be like God, knowing both good and evil" (Genesis 3:5).

In Perelandra the planet Venus is inhabited only by a man and a woman, living in harmony with their environment and with the god Maleldil, who is a metaphor for God. The Green Lady enjoys prelapsarian innocence and youth, unaware of good and evil. In order to tempt her, Weston reverses the categories of good and evil by hinting that being young is but frustrating whereas getting old and dying is what is most desirable. Becoming oneself, autonomous from Maleldil is what Maleldil himself wishes and being separated from him, disobeying him in fact means obeying him. Ransom thwarts Weston's sophism by asserting that obeying Maleldil's voice and will is to do what is good.

By reinterpreting and reparabolizing the original story, Lewis followed a triple purpose. He aimed at reinforcing the plot, increasing the mythopoetic intensity of the story and inserting in it apologetic elements. The Magician is a good example. By resisting the temptation of the forbidden fruit, Digory does what is morally good. $\mathrm{He}$ behaves bravely, saves Narnia and his mother. After his mother eats the magic apple, the apple core is then buried in the family garden. Later on an apple-tree grows out of it but one day a lightening flash uproots it. From its trunk wood a wardrobe will be made and put in Professor Digory's house. That magic wardrobe will allow the magic to go on by enabling the Pevensies children to enter Narnia in the second book of the Chronicles.

Lewis's stories are not just reinterpreted repetitions of metaphoric variants but, like in the parables, they aim at producing and revealing something, both in the author's and the reader's mind. The 'something' produced in literary imagination is what Ladrière calls 'reeffectuation' (Ladrière 51). Firstly, that process starts with interpreting the picture or the story so as to unveil its meaning(s). One could paraphrase Ricœur and assert that the biblical parable, as well as the myth or the symbol, "gives rise to thought". The second step implies appropriating the same story and retelling it in one's own words. The next stage of 'reeffectuation' is to revisit the initial story by introducing personal elements in it because 'reeffectuation' "entails a testimony dimension based on experience" (Ladrière 68). One must bear in mind that Lewis went through a fundamental and founding experience of (re)conversion to Christianity in the early years of his literary career. So spiritual concepts such as 'evil', 'sin', 'temptation', 'repentance', resonated first with his inner experience before becoming literary material. Lewis's self-implication in his fiction was first and foremost existential. Then his handling of these religious notions depended on the author's stance: at times Lewis could be a mythopoet or a scholar and a teacher but he could also be a formidable apologist or a vulnerable autobiographer. The temptation scene provides us with a case in point.

In The Pilgrim, Mother Kirk explains to John that the Great Canyon is an inescapable prerequisite in his intellectual, spiritual and aesthetic journey. In Perelandra, Lewis got involved indirectly through Ransom (a scholar fond of ancient languages like him) who witnesses the temptation scene and, like an apologist, counters the tempter Weston philosophically and theologically. In The Magician, Lewis incorporated a tragic event from his youth: his mother's disease and death. But in the tale, the event has been 
sublimated. Contrary to Lewis's reality, the young boy managed to save his mother's life. The fourth reeffectuation level operates in the reader's reception of the story. It is supposed to function as a reminder of the initial event (told in the Bible) that reverberates in the reader's personal story (temptation as a personal issue). How did Lewis intend to make something new happen in an old revisited story? By "irrigating the deserts" of the reader's imagination (Lewis 1947, 27). In the same way as the biblical parable-story echoes in the listener's imagination and memory, the Lewisian story is supposed to reverberate in each and everyone's personal story. That is why it is ultimately performative.

In his analysis of literary imagination Adolphe Gesché's underlined that "Literature acts; it does not merely show or entertain. It has a power of revelation [...] it is where epiphanies occur.":

There is an analogy between fiction discovery and what theologians call revelation: a visitation, an encounter with something unexpected, sudden, "revealed", out of the daily routine and yet inscribed in it. In revelation, there lies a part of an enigma (Moses and the burning bush), plot (Jacob's struggle with the angel). Exactly like in literature. A plot evolves from an enigma, which is part and parcel of it (Ricœur, Lévinas). From that, free to move, I try to build and understand myself and start to reveal myself to me." (Gesché 151,154$)^{7}$

So it appears that literary imagination has a revealing effect on the reader let alone theology, i.e. the discourse on God. It is all the more so when a story combines imagination and spirituality, which is the case with Lewis. In order to be accessible, theology produces revelation through imagination by means of metaphors that saturate the entire Bible (e.g. Jesus is the good shepherd, the bread of life, etc.). Theology makes sense because it is embodied in pictures, metaphors and analogies.

From the mythic stories which it resorts to in the Old Testament to the lively metaphors that crisscross all the New Testament, the Judeo-Christian kerygma does nothing but appeal to our imagination like a groundswell and a tight back drop. The stupendous story of the creation does nothing but tune (like a cord instrument) the story of faith to the mythic tales of Adam's shaping, Eve's arrival out of a dream, a wonderful and dangerous garden in which man trains himself to be free, in which cosmic tragedies like the Tower of Babel or the Flood unfold the splendor of their immemorial pictures (Ladrière 156-7). ${ }^{8}$

18 Man's revelation of God and of man occurs through the prism of imagination. It happens from a triple enigma stemming from, firstly, the "Deus absconditus, the hidden God dear to Pascal and Isaiah" (Gesché 162) but also from man as an enigma to himself and to God. So revelation, in order to be more efficient, requires to be mediated by another story. To highlight that triple enigma (even quadruple if one considers the enigma of God Incarnate for God the Father), "a story told by someone else and surrounded by the magic of a story is necessary" (Gesché 164). And here comes the parable as an intermediate story that links theology and imagination, recalling both a universal and intimate experience. To finish, Gesché marvels at Saint Bernard's statement that "God descended into our very imagination". "What is remarkable is that Saint Bernard uses the vocabulary of the incarnation, 'descended'. God descended into our imagination, when he came down into flesh" (Gesché 182). ${ }^{9}$

The biblical parable is one expression of that embodiment of the Word in human imagination. To a lesser extent, for the novelist Lewis, his parable-stories were bound to overlap the initial story which they reflected and reactivated. For the apologist 
Lewis, irrigating his theology and philosophy by the streams of imagination and poetry appeared to be the best way for his testimony to satisfy reason, faith, and affectivity.

\section{BIBLIOGRAPHY}

Gesché, Adolphe. Dieu pour penser. Tome VII Le sens. Paris: Cerf, 2003.

Ladrière, Jean. L'articulation du sens. Les langages de la foi. Paris: Cerf, 1984.

Lewis, Clive Staples. The Pilgrim's Regress: an Allegorical Apology for Christianity, Reason and Romanticism. London: J.M. Dent, 1933.

---. The Abolition of Man. London: Macmillan, 1947

--- Perelandra. London: John Lane, The Bodley Head, 1943; The Magician's Nephew. London: The Bodley Head, 1955.

Ricœur, Paul. Finitude et culpabilité, II, Paris : Aubier Montaigne, 1960, pp 398-9.

---.La Bible et l'imagination. Revue d'histoire et de philosophie religieuse, 1982, n4, pp 339-60.

\section{NOTES}

1. The Pilgrim's Regress (1933), a palimpsest of Bunyan's Pilgrim's Progress (1678) is a spiritual autobiography written as an allegory in which Lewis justified his Christian faith rationally.

2. Traduction de l'auteur. « Tout acte de parole est auto-implicatif [...] De telle sorte que, dans sa parole, le sujet parlant met en jeu son être même, selon les différentes modalités qui le spécifient comme être-sujet (modalités de la connaissance, du vouloir, de l'imaginaire, de l'affectivité, de la sensibilité, de la communication, etc.), et selon des degrés d'intensité qui varient avec la nature des actes illocutionnaires qu'il accomplit. Cela signifie d'une part qu'il fait nécessairement passer dans ce qu'il dit ce qui constitue la trame même de son existence, que, en ce sens, sa parole est vraiment l' « expression » de lui-même. Mais cela signifie aussi, d'autre part, que le langage, dans la mesure où il l'assume, retentit sur le mouvement même de son existence et donne à celle-ci sa forme. S'il y a passage expressif de l'existence dans la parole, il y a aussi, en sens inverse, effet inducteur de la parole sur l'existence. C'est pourquoi on ne peut user du langage de façon neutre; il y a une irréductible gravité de la parole, et une responsabilité indéclinable à l'égard de ce qu'elle accomplit.»

3. Il faut considérer l'imagination « comme pouvoir de donner forme à l'expérience humaine [...] c'est par ces fictions que nous donnons une forme narrative à notre expérience individuelle ou commune.»

4. Traduction de l'auteur. "Le récit évangélique tout entier s'organise autour d'une péripétie unique qui est l'accomplissement des promesses, la substitution d'une nouvelle alliance à celle de l'ancienne Loi, la proclamation-réalisation de la Parole de Dieu, du «mystère caché aux siècles et aux générations passées, mais manifesté maintenant " aux saints de Dieu (Col. 2:27), de «ce mystère qui est le Christ. Or cette péripétie n'est pas présente dans une évidence immédiate. »

5. Traduction de l'auteur. "Le récit-parabole est un itinéraire de sens, ouverts sur un travail d'interprétation. " 
6. Traduction de l'auteur. «[...] l'homme n'est pas le méchant absolu; il n'est que le méchant en second, le méchant par séduction; il n'est pas le Mauvais, le Malin, substantivement si l'on peut dire, mais mauvais, méchant par épithète; il se rend méchant par une sorte de contreparticipation, de contre-imitation, par consentement à une source de mal que le naïf auteur du récit biblique dépeint comme ruse animale. Pécher c'est céder. »

7. Traduction de l'auteur. «La littérature agit, elle n'est pas simple spectacle ou divertissement. Elle a un pouvoir de révélation. [...] Elle est le lieu des épiphanies. [...] Il y a dans la découverte romanesque une analogie avec ce que le théologien appelle Révélation: une visitation, la rencontre de quelque chose d'inattendu, de soudain, de "révélé ", hors du réel quotidien et cependant inscrit en lui. Il y a dans la révélation une part d'énigme (Moïse devant le Buisson), d'intrigue (combat de Jacob avec l'ange). Comme dans la littérature, très exactement. C'est à partir de l'énigme, qui est tout son contenu et toute sa raison, que se développe une intrigue (Ricœur, Levinas), à partir de laquelle, libre de mes mouvements, je cherche à me construire et à me comprendre et commence à me révéler à moi-même »

8. Traduction de l'auteur. «Depuis les récits mythiques auxquels il recourt dans son Ancien Testament, jusqu'aux métaphores vives qui sillonnent tout son Nouveau Testament, le kérygme (judéo)chrétien ne fait pas autre chose que de solliciter, comme une vague de fond et un décor toujours tendu, notre imaginaire. L'immense récit de la Création dans la Genèse ne fait pas autre chose que d'accorder, comme on dit d'un instrument à cordes, le récit de sa foi en Dieu aux récits mythiques du modelage d'Adam, de la venue d'Eve au cœur d'un rêve, d'un jardin merveilleux et dangereux où l'homme s'exerce aux premiers pas de la liberté, où des drames cosmiques comme Babel et le Déluge déploient le faste de leurs images immémoriales. »

9. «Dieu est descendu jusque dans notre imagination.» Et ce qui est remarquable, c'est que Bernard emploie le vocabulaire même de l'Incarnation: descendit, il est descendu jusque dans notre imagination, quand il est descendu parmi nous dans la chair. »

\section{ABSTRACTS}

Based on Paul Ricœur's conceptual analysis of the Gospels' parables, this paper will aim at showing how C.S. Lewis (1898-1963) resorted to parable telling as a way of metaphorizing his apologetic discourse. By revisiting foundational texts (cosmogonic stories, temptation scenes in a garden, repetition of lapsarian stories, experiences of inner conversion) inserted in his fiction (The Pilgrim's Regress, The Chronicles of Narnia, Perelandra), Lewis appropriated that aesthetic and religious heritage which he reactivated by introducing his personal experience and his aesthetic, philosophical and religious quest in it. That experience echoed universal experience and Saint Paul's and Saint Augustine's conversion stories. Owing to its exemplarity, the performativity of the Lewisian parable can be inscribed within a network of similar human experiences (Ladrière). Therefore it is overdetermined by its intertextuality and the different subjective layers it refers to: the original experience, the author's own experience and the reader is invited to experiment the same experience. The evangelical parable describes a two-fold movement: the kingdom of God is staged through Jesus' story which itself is inscribed within men's history then becoming the history of salvation (both seen as universal and a tell-tale story). To a lesser extent, Lewisian stories describe that oscillation: various protagonists are staged both in a singular and universal story. 
Partant de l'analyse conceptuelle de Paul Ricœur sur les paraboles de l'Évangile, le propos de cet article vise à montrer comment C.S. Lewis (1898-1963) a recours à la parabolisation pour métaphoriser son discours apologétique. Par sa réécriture de textes fondateurs (récits cosmogoniques, scènes de tentation dans un jardin, répétition de la chute, expériences de conversion intérieure) qu'il insère dans sa fiction (Pilgrim's Regress, Chroniques de Narnia, Perelandra), Lewis se réapproprie ce patrimoine esthétique et religieux qu'il réactive en y introduisant son expérience personnelle singulière (sa quête/conversion esthétique, philosophique et religieuse), qui, elle-même entre en résonance avec l'expérience universelle (celle de Saint Paul ou de Saint Augustin). Par son exemplarité, cette performativité de la parabole lewisienne, s'inscrit comme un maillon de plus dans la chaîne des expériences humaines (Ladrière). Ainsi la parabole lewisienne est-elle surdéterminée par son intertextualité et par les différentes strates subjectives auxquelles elle fait allusion: expérience originelle, expérience personnelle (de l'auteur), invitation au lecteur à vivre la même chose. La parabole évangélique rend compte d'un double mouvement: le royaume de Dieu se met en scène au travers de l'histoire («story») de Jésus qui s'inscrit elle-même dans l'histoire (" history») des hommes et devient ainsi l'histoire du salut (à la fois «story » car racontée comme un conte/récit et « history» par sa dimension universelle). A un moindre degré, la parabole lewisienne décrit et décline cette même oscillation : mise en scène des différents acteurs dans une histoire singulière et universelle.

\section{INDEX}

Keywords: (re)effectuation, imagination, parable, performativity, Jean Ladrière, C.S. Lewis, Paul Ricœur

\section{AUTHOR}

\section{DANIEL WARZECHA}

Professeur agrégé docteur en Études Anglophones

PRAG

Université de Lille 3, France.

daniel.warzecha@univ-lille3.fr 